Acta Theriologica $36(3-4): 207-227,1991$.

PL ISSN $0001-7051$

\title{
Population dynamics and demography of the bank vole in different tree stands
}

\author{
Maria MAZURKIEWICZ
}

\begin{abstract}
Mazurkiewicz M. 1989. Population dynamics and demography of the bank vole in different tree
\end{abstract} stands. Acta theriol. 36: $207-227$.

The seasonal and multi-annual changes in numbers and demography of the population of Clethrionomys glareolus (Schreber, 1780) in nine different stands which differed in spatial structure and plant species were analyzed. The density and distribution of the undergrowth influenced the density and demography of the population. On plots where the undergrowth was more evenly distributed (random) there was a higher density than on plots where it was clustered. The multi-annual cycle showed a synchronization of density changes (across all plots). The number of sexually active males and females decreased as the clumping of undergrowth increased. The number of recruits to the population was proportionate to the number of sexually active females at the beginning and end of the reproductive season. In late summer there was a decrease in recruitment to the population, especially on plots with randomly distributed undergrowth. The number of recruits to the population in a given trapping series was inversely related to the number of individuals persisting from the previous trapping series. The higher survival rates of individuals marked in the early summer on plots with random dispersion of undergrowth caused the age structure of the individuals on these plots to "become older" than on plots with clustered undergrowth. These results are in agreement with Anderson's model for utilization of habitats along a decreasing gradient of suitability for the bank vole and indicate that processes regulating the population most effectively occur early in the season.

Department of Vertebrate Ecology, Institute of Ecology, Polish Academy of Sciences, Dziekanów Leśny, 05-092 Łomianki, Poland

Key words: Clethrionomys glareolus, demography, population dynamics, habitat structure

\section{Introduction}

In light of previous studies, it appears incontestable that not only food availability, (Thomson 1955, Pitelka 1957, Kalela 1962, Fordham 1971, Taitt and Krebs 1981, Van Horne 1981, and others), but also habitat structure influences the numbers and distribution of many forest rodent species (Newson 1963, Ashby 1967, Birkin 1968, M'Closkey 1975, Abramsky 1981, Mazurkiewicz 1984, Adler 1986, Adler and Wilson 1987, and others). The main habitat factors influencing the occurrence and population density of a given species are those which permit survival and the bearing and weaning of young. The capacity of a given habitat for small rodents will depend then on the availability of food and those habitat attribiutes that provide shelter (Miller and Getz 1972, 1973, 1977; Gubar 1974, Crowell and Pimm 1976, Goodwin and Hungerford 1979, Smal and Fairley 1981, Van Horne 1981, Jensen 1982).

The bank vole (Clethrionomys glareolus Schreber, 1780) occurs in all types of forests over its geographical range (Hansson 1971). However, in forest ecosystems of similar and high 
soil fertility, populations of this species differ in density (Kowalewski et al. 1971, Kowalewski and Korenberg 1978, Mazurkiewicz and Rajska-Jurgiel 1978, Jensen 1982, Mazurkiewicz 1984). It has been found that the density and distribution of the bank vole in forests depends on the density and type of distribution of habitat attributes, such as debris, slash, ferns and undergrowth (Evans 1942, Brown 1956, Koshkina 1957, Lapin 1963, Petroy 1965, Popov 1966, Ivanter 1975, Hansson 1978, Jensen 1982, Wiger 1982, Mazurkiewicz 1984, 1986). A similar influence of structural elements of the forest environment, which may be very different but play the same protective role from predators, suggests that the composition of space in which a given population lives has an important influence on the density of rodents.

Many authors have found that the density of small rodents differs among forest habitats, but only at low population densities. An increase in population numbers causes a decrease in the differentiation of the density (Gubar 1974, M'Closkey 1981, Van Horne 1981). Bank Vole population densities may however be different even in neighboring forest habitats of similar soil fertility though with different degrees of refuge capacity (i.e., Jensen 1982, Mazurkiewicz 1984). In the former case (equilibration of density between habitats) dispersal would be implicated as primary factor in population regulation. An increase in the population density in optimal habitats would cause an emigration of individuals to suboptimal habitats. In the end, there would be a decrease in density variation among habitats. In the second case (maintenance of different densities between habitats), numbers would become controlled more locally within a given habitat according to the food and shelter capacity of the habitat. This could occur through reproduction control (i.e., inhibition of sexual maturation) and individual emigration in search of appropriate areas for residency which, in this situation mostly ends in failure (Lidicker 1975, Errington 1983). As a result of such density regulation, differences in habitat population densities would be maintained.

Many authors have confirmed that density alone is not a good indicator of the quality of the habitat unless it is also based on other population parameters which give evidence of high or low fitness of individual members of the population (Viitala 1977, Wiger 1982, Van Horne 1983, Adler and Wilson 1987). Reports indicate that a higher percentage of reproducing individuals occur in patches of preferred habitats than of sub-optimal habitats (Cockburn 1981, Cockburn and Lidicker 1983, Ostfeld et al. 1985, Spencer and Cameron 1983, Kozakiewicz 1985). In such habitats there is a considerable prevalence of females (Bowers and Smith 1979, Ostfeld and Klosterman 1986) and a larger proportion of mature individuals (Van Horne 1981, 1982a, 1982b).

Previous studies of the same data have shown that bank vole densities in different types of tree stands were positively correlated with the density of the undergrowth (Mazurkiewicz 1984). Additionally, it was found that the type of undergrowth distribution influenced the space utilization by individuals of the bank voles (Mazurkiewicz 1986). As the percent cover of the undergrowth increased the bank voles used more space at the similar density. The spatial distribution of the undergrowth also had an influence on the way the population used space. As clumping of the undergrowth increased, the amount of space used decreased. A comparison of the spatial organization of the population living on plots with random and clustered undergrowth distribution indicated that individuals in the latter habitat showed a slower rate 
of occupation of empty space, had higher local densities and had smaller home ranges over the entire range of densities than did the individuals living on plots with random undergrowth distribution. The spatial structure of sexually active females was similar on both types of plots (Mazurkiewicz 1986).

The purpose of the present study was to investigate whether distribution of undergrowth (density, percentage cover, type of spatial distribution), which determines the sheltering capability of a habitat, influences the seasonal and multi-annual dynamics of the bank vole population and, if so, which demographic processes play a major role in producing this pattern.

\section{Material and methods}

Studies were carried out from 1976 to 1981 in the Puszcza Piska forest complex $\left(53^{\circ} 40^{\prime} \mathrm{N}, 21^{\circ} 35^{\prime} \mathrm{E}\right.$, Mazurian lake district) in nine stands. The duration of the studies on different plots varied and did not span the same years (Fig. 1). The methodology for gathering information was based on the Catch-Mark-Release (CMR) method. On each 1,4 hectare study plot, 64 live traps were set at $15 \mathrm{~m}$ grid intervals. Every year from spring (end of May) to autumn (mid-October), four trapping series were carried out at 46-day intervals.

During each trapping series, lasting seven days, the traps were checked twice daily. The captured individuals were marked by toe-clipping (amputation of the final digit of a toe), and the date and place of capture noted. Body weight, sex and sexual activity (females - open or closed vagina; male - testes scrotal or not) were also recorded.

The study plots were located in nine of the most common types of tree stands existing in the Puszcza Piska forest complex. The areas of particular stands varied from 10 to 20 hectares. Four study plots were located in natural tree stands: oak-hornbeam forests (Tilio-Carpinetum) $0-260$ yrs. old (plot $C_{1}$ ), $0-120$ yrs. (plot $\mathrm{C}_{2}$ ); moist coniferous forest (Sphagno-Piceetum girgensolnii) $0-120$ yrs. (plot $\mathrm{C}_{3}$ ) and mixed-coniferous forest (Pino-Quercetum) 0 - $144 \mathrm{yrs}$. (plot $\mathrm{R}_{8}$ ). The remaining plots were located in pine monocultures and a pine-spruce forest situated in a mixed coniferous forest habitat. The pine monocultures were $0-10 \mathrm{yrs}$, old (plot $\mathrm{C}_{6}$ ), $0-15 \mathrm{yrs}$. (plot $\mathrm{R}_{5}$ ), $0-90 \mathrm{yrs}$. (plot $\mathrm{R}_{7}$ ), $0-140$ yrs. (plot $\mathrm{R}_{4}$ ), and a pine-spruce forested plot 0 -110 yrs. (plot $\mathrm{C}_{9}$ ). To characterize the habitat of each study plot, in addition to determining the stand age and phyto-sociological forest type, the tree and undergrowth species composition, density and spatial distribution were noted. For this purpose, from 40 to 75 squares (depending on the degree of heterogeneity of the stand), 100 square meters in area were marked out on each plot and all trees and shrubs were counted. The herb layer was characterized by list of species and percent cover of the area of each plot.

The particular plots differed in tree species richness (from two to thirteen species). Among conifers, pine (plots $\mathrm{C}_{2}, \mathrm{R}_{4}, \mathrm{R}_{5}, \mathrm{C}_{6}, \mathrm{R}_{7}$, and $\mathrm{R}_{8}$ ) or spruce (plots $\mathrm{C}_{1}, \mathrm{C}_{3}$, and $\mathrm{C}_{9}$ ) dominated. On the majority of plots, numerically dominant hardwoods were the hazel (any individuals above $6 \mathrm{~m}$ were considered to be trees), hornbeam (plots $C_{1}, C_{2}$, and $R_{8}$ ), and birch (plots $C_{3}$ and $C_{6}$ ) (Table 1).

The undergrowth was comprised of one to fourteen species of shrubs and saplings. Hornbeam and ash dominated on plots $C_{1}$ and $C_{2}$, spruce on $C_{3}$. Hazel alone was predominant on plots $R_{4}, R_{7}, R_{8}$, along with spruce on plot $\mathrm{C}_{9}$ and pine on plot $\mathrm{R}_{5}$. Birch and pine were the most common undergrowth on plot $\mathrm{C}_{6}$. Study plots were characterized by various densities and various undergrowth distributions (random were noted by the letter R, and clustered by C), (Table 1).

The herb layer was very rich in numbers of species (20 to 47 species) and covered $30-90 \%$ of the area of particular plots. The most numerous species within the pine monocultures were: Calamagrostis arundinacea, Oxalis acetosella, and Vaccinium myrtillus. Galeobdolon luteum was found most often within oak-hornbeam forests and Lycopodium annotinum within the moist coniferous forest (Table 1).

The analyzed data included 11,205 captures of 3149 bank voles. In addition to the bank vole, there were occurences of Apodemus flavicollis (Melchior, 1834) and Microtus agrestis (Linnaeus, 1761). 


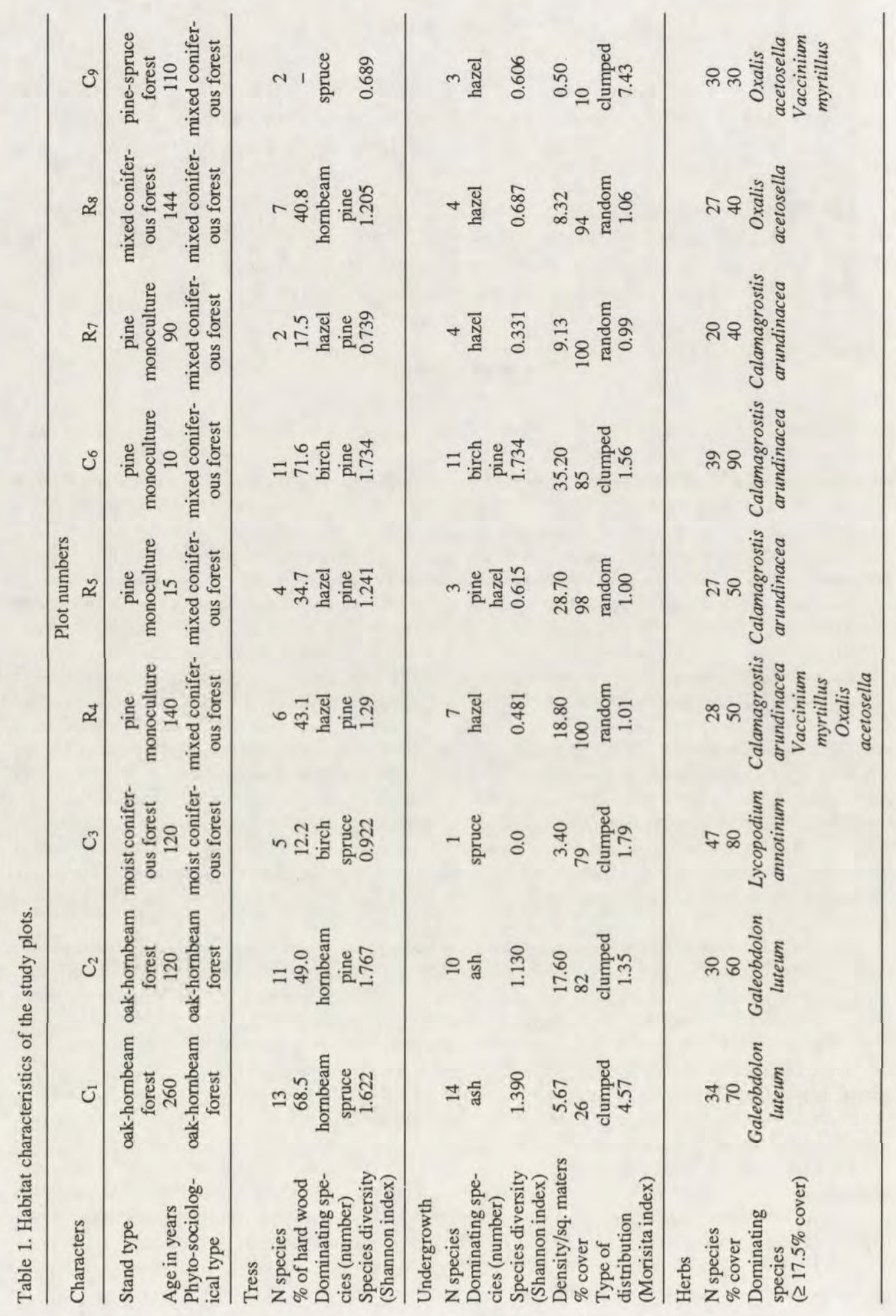




\section{Results}

\section{The influence of habitat variables on population density}

The influence of eight selected tree stand structure variables on population density was studied (Table 2). Statistically significant correlation coefficients were found for population density and the following variables: density, type of distribution and percent cover of undergrowth. No significant correlations were observed between population density and age and tree species richness, undergrowth species richness, and herb species richness and percent cover of herb layer (Table 2).

On the basis of these and earlier results from the same material (Mazurkiewicz 1984, 1986), the undergrowth was found to be the most important element of stand structure for the bank vole on the studied habitats.

Table 2. Correlation coefficient $(r)$ and statistical significance $(p)$ for the habitat variables and population density.

\begin{tabular}{lrc}
\hline Habitat variables & $r$ & $p$ \\
\hline $\begin{array}{l}\text { Tree stand age } \\
\text { Tree species diversity } \\
\quad \text { (Shannon index) }\end{array}$ & -0.583 & NS \\
$\begin{array}{l}\text { Undergrowth species diversity } \\
\quad \text { (Shannon index) }\end{array}$ & 0.462 & NS \\
$\begin{array}{l}\text { Undergrowth density } \\
\text { Type distribution of undergrowth }\end{array}$ & 0.300 & NS \\
$\quad$ (Morista index) & 0.882 & $<0.001$ \\
$\%$ cover of undergrowth & 0.919 & $<0.001$ \\
$\%$ cover of herb layer & 0.827 & $<0.001$ \\
Herb species richness & 0.246 & NS \\
\hline
\end{tabular}

Dispersion of the undergrowth cover was characterised using Morisita's index, (Morisita 1959). I chose two look at dispersion becouse there was a significant correlation with the remaining undergrowth characteristics (with undergrowth density, $r=-0.835, p<0.01$; percentage of area covered by undergrowth, $r=-0.972, p<0.001$ ). The data which I had available did not always allow for analysis of population parameters along a gradient of undergrowth clustering. In these cases, the plots were grouped into two types depending on distribution of undergrowth, random (type R) and clustered (type C) for analysis.

\section{Seasonal and multi-annual density changes}

Bank vole densities were evaluated using the MNP (Minimum Number Present) method for all trapping series in each year. Seasonal changes in population density on different plots were parallel. In the spring (end of May), when the population was composed of overwintered individuals, density was low, but differed among plots. The spring density depend on the previous year's fall density $(r=0.646, p<0.01, \mathrm{n}=17)$. Density increased rapidly during the 


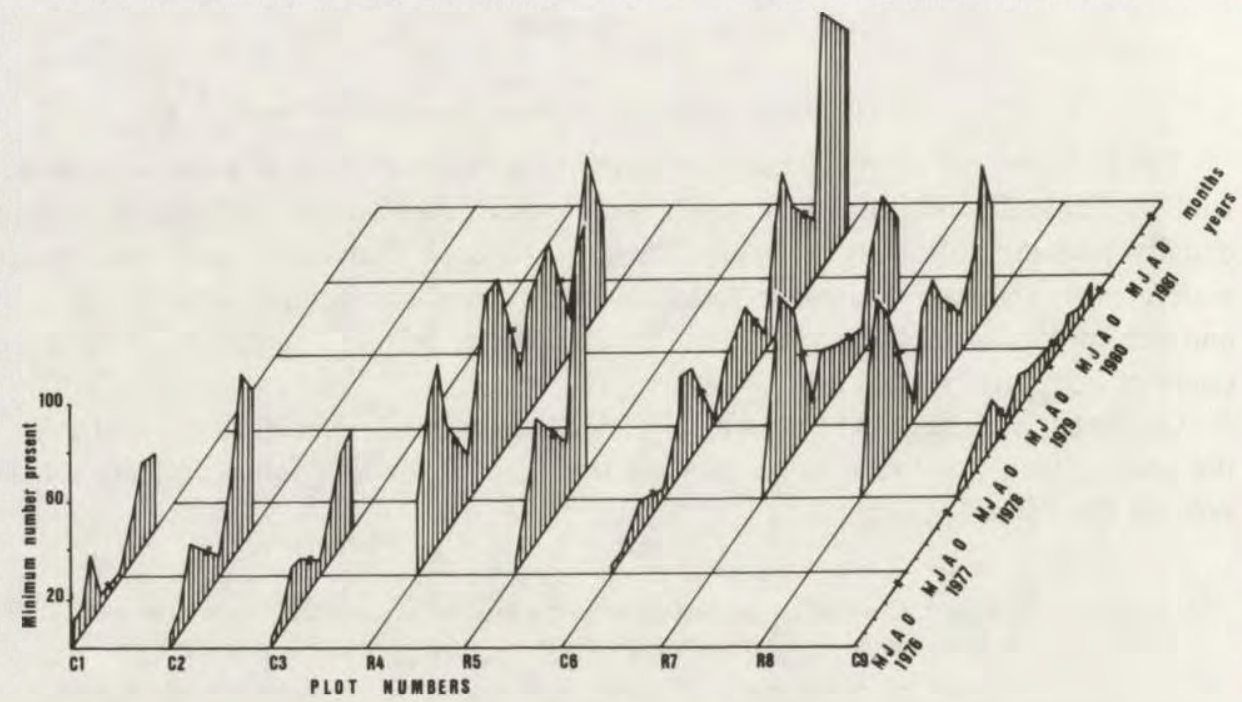

Irig. 1. Seasonal changes in the population density of the bank vole (MNP) on different plots.

Table 3. The mean density $(\bar{x})$ on type $\mathrm{R}$ and $\mathrm{C}$ plots in the season calculated for (1) the entire data set and (2) for data from two years only.

\begin{tabular}{|c|c|c|c|c|c|c|c|}
\hline \multirow{2}{*}{ Month } & & \multicolumn{2}{|c|}{$\mathrm{R}$} & \multicolumn{2}{|c|}{ C } & \multirow{2}{*}{$t$} & \multirow{2}{*}{$p$} \\
\hline & & $\bar{x}$ & SD & $\bar{x}$ & SD & & \\
\hline \multirow[t]{2}{*}{ May } & 1 & 13.3 & 7.50 & 5.4 & 5.84 & 2.93 & $<0.01$ \\
\hline & 2 & 12.0 & 7.76 & 4.3 & 2.93 & 2.66 & $<0.02$ \\
\hline \multirow[t]{2}{*}{ July } & 1 & 39.2 & 15.05 & 22.8 & 24.13 & 2.33 & $<0.05$ \\
\hline & 2 & 43.1 & 19.92 & 15.0 & 12.06 & 3.35 & $<0.002$ \\
\hline \multirow[t]{2}{*}{ Aug. } & 1 & 61.2 & 18.52 & 33.8 & 24.02 & 3.09 & $<0.01$ \\
\hline & 2 & 59.9 & 21.59 & 30.7 & 19.71 & 2.96 & $<0.01$ \\
\hline \multirow[t]{2}{*}{ Oct. } & 1 & 47.2 & 17.13 & 30.5 & 21.83 & 2.18 & $<0.02$ \\
\hline & 2 & 51.4 & 19.61 & 27.4 & 17.05 & 2.73 & $<0.02$ \\
\hline
\end{tabular}

period from the end of May to mid-July. The highest population density was observed most commonly at the end of August (Fig. 1). During some years, the highest density was observed in mid-July or October (in such cases the differences in numbers in relation to August ranged between one to eight individuals only). This occurred more often on $\mathrm{C}$ plots (seven cases) than on R plots (two cases).

Throughout the study period trapping was not conducted simultaneously on all plots. Therefore the seasonal changes in population density on $\mathrm{R}$ and $\mathrm{C}$ plots within years could not be compared directly. The basis for comparison was the mean density in successive trapping series for each type of plot calculated in two ways. First, the mean was calculated for data 


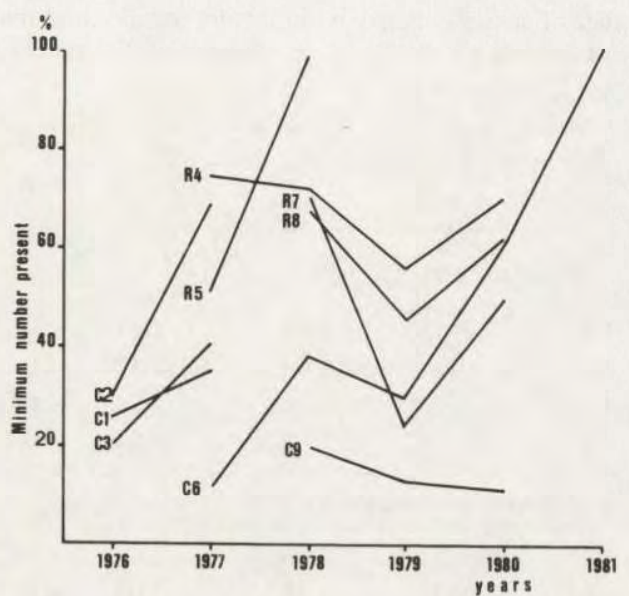

Fig. 2. Peak population density on different plots in subsequent years.

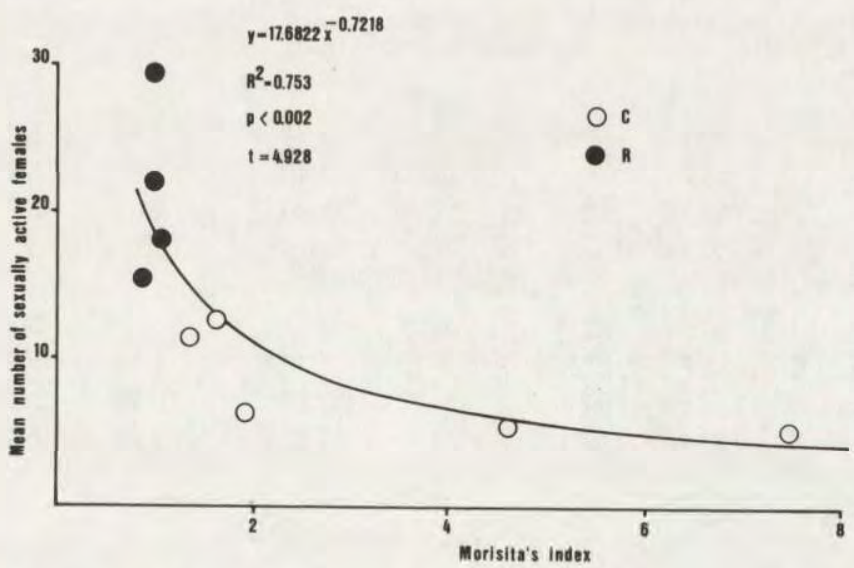

Fig. 3. The relationship between the mean number of sexually active females in the reproductive season and the value of the Morisita index of the undergrowth in specific plots.

from all the years studied, and in the second the data from two years for each plot were analyzed. If, on a given plot the studies lasted longer than two years, the years with maximum and minimum densities were used for analysis. Thus the varying length of periods during which a plot was studied did not have any effect on the mean. The $t$-test was used for comparisons.

During the entire season the population density was significantly higher on R than on C plots. Statistically significant differences were obtained from analysis of both the entire experimental data set (method 1, Table 3 ) and the selected years (method 2, Table 3 ).

Multi-annual density changes on different plots were synchronous. Densities on plot pairs changed in the same direction (increasing or decreasing) on most plots (fourteen of sixteen cases). Low population densities were observed in 1976 and 1979, and high in 1978 and 1981 (Fig. 2). The 1981 data were from plot $\mathrm{C}_{6}$ only so was not considered in further analysis. 
Table 4 . The mean number of sexually active and inactive females and males $(\bar{x}, \mathrm{SD})$ at various months. Student $t$-values and significance of differences $(p)$ between the means of type $\mathrm{R}$ and $\mathrm{C}$ plots.

\begin{tabular}{|c|c|c|c|c|c|c|}
\hline \multirow{2}{*}{ Month } & \multicolumn{2}{|c|}{$\mathrm{C}$} & \multicolumn{2}{|c|}{$\mathrm{R}$} & \multirow{2}{*}{$t$} & \multirow[b]{2}{*}{$p$} \\
\hline & $\bar{x}$ & SD & $\bar{x}$ & SD & & \\
\hline \multicolumn{7}{|c|}{ Sexually active females } \\
\hline May & 1.86 & 1.81 & 5.92 & 5.92 & 2.34 & $<0.05$ \\
\hline June & 6.36 & 4.95 & 12.75 & 4.06 & 3.42 & $<0.01$ \\
\hline Aug. & 5.43 & 4.22 & 12.42 & 7.01 & 2.98 & $<0.02$ \\
\hline Oct. & 0.50 & 0.82 & 1.82 & 1.85 & 2.64 & $<0.05$ \\
\hline \multicolumn{7}{|c|}{ Sexually active males } \\
\hline May & 2.43 & 3.09 & 5.83 & 3.60 & 2.49 & $=0.02$ \\
\hline June & 6.86 & 6.65 & 11.42 & 3.48 & 2.07 & $<0.05$ \\
\hline Aug. & 5.29 & 3.63 & 9.92 & 3.88 & 3.01 & $<0.01$ \\
\hline Oct. & 0.21 & 0.56 & 0.42 & 1.12 & 0.57 & NS \\
\hline \multicolumn{7}{|c|}{ Sexually inactive females } \\
\hline May & - & & - & & & \\
\hline June & 2.86 & 4.70 & 5.67 & 5.17 & 1.39 & NS \\
\hline Aug. & 9.57 & 9.46 & 16.50 & 7.46 & 1.97 & NS \\
\hline Oct. & 15.43 & 11.78 & 22.00 & 8.06 & 0.61 & NS \\
\hline \multicolumn{7}{|c|}{ Sexually inactive males } \\
\hline May & 0.71 & 1.28 & 0.75 & 1.01 & & NS \\
\hline June & 6.77 & 7.05 & 8.42 & 5.39 & 1.51 & NS \\
\hline Aug. & 12.36 & 10.83 & 21.67 & 7.89 & 0.78 & NS \\
\hline Oct. & 15.14 & 11.15 & 22.96 & 7.56 & 1.95 & NS \\
\hline
\end{tabular}

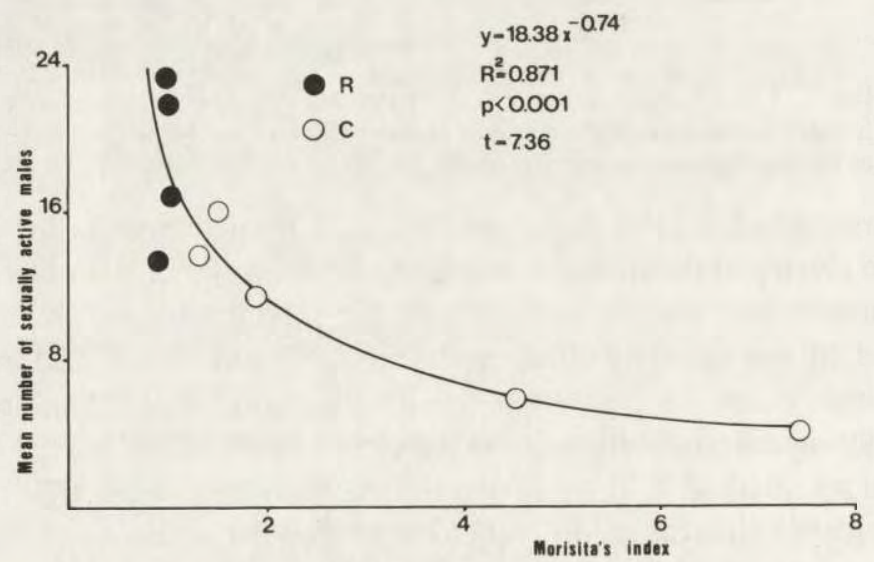

Fig. 4. The relationship between the mean number of sexually active males in the reproductive season and the value of the Morisita index in specific plots. 


\section{Reproduction}

Number of sexually active individuals and the type of undergrowth distribution

Seasonal changes in density on $\mathrm{R}$ plots were significantly higher than on $\mathrm{C}$ plots. Density and distribution of the undergrowth, which probably served as shelter from predators, may limit the amount of space suitable for reproduction and, consequently, the number of sexually active individuals on the plots.

The correlation between the Morisita index values and the mean number of sexually active males and females was estimated. The mean was calculated on the basis of all the data. It was found that the number of sexually active individuals, both male and female, decreased as the clumping of the undergrowth increased (Figs 3 and 4). The mean number of sexually active individuals, especially females, present in the population during a season was higher on $\mathrm{R}$ plots than on C plots.

The higher total number of sexually active individuals on $\mathrm{R}$ plots was checked to see whether it was caused by higher turnover of individuals on these plots as compared with C plots. The percent of individuals present in two or more trapping series was than compare using the data from all years studied on each type of plot. It was found that, the percentage of individuals present in two or more trapping series was similar for both types of plots for both sexually active females and males. For type R the values were $58 \%$ for both females and males, and for type C, $52 \%$ for females and $55 \%$ for males.

\section{Stabilization of sexually active individuals}

Seasonal changes in the density of sexually active individuals on type $\mathrm{R}$ and $\mathrm{C}$ plots should accompany changes in the entire population as long as reproduction is not limited.

For consecutive trapping series the mean number of sexually active and inactive females and males on each type of plot was copmared using data from all the years of the study (Student $t$-test). The mean number of sexually active males and females during the subsequent trapping series was significantly higher on type R plots than on type C plots (Table 4). During the period of intensive reproduction (July - August), the number of sexually active individuals was much more stable than the number sexually inactive individuals, which increased significantly during this time on both types of plots. The mojority of the sexually females and males $(79-97 \%)$ were overwintered individuals and born at the beginning of the season (marked in July).

The correlation between the number of sexually active individuals and the total number of individuals of a given sex was calculated. Data from a trapping series in May, July and August (reproductive season) of all years studied were analyzed for each plot. Plot $\mathrm{C}_{3}$ was not analyzed becouse of insufficient data.

A positive curvilinear regression between the number of sexually active females and total number of females was observed on the majority of plots (Fig. 5, Table 5). The only difference was on plots $\mathrm{R}_{5}$ and $\mathrm{C}_{6}$ where the increase in number of sexually active females was proportionate to the increase in total number of females (linear regression) (Fig. 5). The remainder of the plots showed an inhibition in the increase of numbers of sexually active females occurring at various total number of females. 
Table 5. The relationship between the number of sexually active females (y) and the total number females (x) on separate plots (see Fig. 5).

\begin{tabular}{lclcc}
\hline Plot & $\begin{array}{c}\text { Sample } \\
\text { size }\end{array}$ & Regression equation & $R^{2}$ & $\begin{array}{c}\text { Significance } \\
\text { of equation }\end{array}$ \\
\hline $\mathrm{C}_{1}$ & 6 & $\mathrm{y}=0.6981 \mathrm{x}-0.02878 \mathrm{x}^{2}+0.4708$ & 0.833 & $0.1>p>0.05$ \\
$\mathrm{C}_{2}$ & 6 & $\mathrm{y}=0.81094 \mathrm{x}-0.01413 \mathrm{x}^{2}-0.04362$ & 0.830 & $0.1>p>0.05$ \\
$\mathrm{C}_{3}$ & - & - & - & - \\
$\mathrm{C}_{6}$ & 14 & $\mathrm{y}=0.3967 \mathrm{x}+1.2822$ & 0.913 & $p<0.001$ \\
$\mathrm{C}_{9}$ & 9 & $\mathrm{y}=0.750 \mathrm{x}-0.1111$ & 0.610 & $p<0.01$ \\
$\mathrm{R}_{4}$ & 12 & $\mathrm{y}=1.6615 \mathrm{x}-0.02889 \mathrm{x}^{2}-4.7685$ & 0.871 & $p<0.001$ \\
$\mathrm{R}_{5}$ & 6 & $\mathrm{y}=0.40404 \mathrm{x}+2.8608$ & 0.878 & $p<0.01$ \\
$\mathrm{R}_{7}$ & 9 & $\mathrm{y}=1.3754 \mathrm{x}-0.03624 \mathrm{x}^{2}-1.1998$ & 0.896 & $p<0.005$ \\
$\mathrm{R}_{8}$ & 9 & $\mathrm{y}=4.08851 \mathrm{nx}-1.1923$ & 0.588 & $p<0.02$ \\
\hline
\end{tabular}

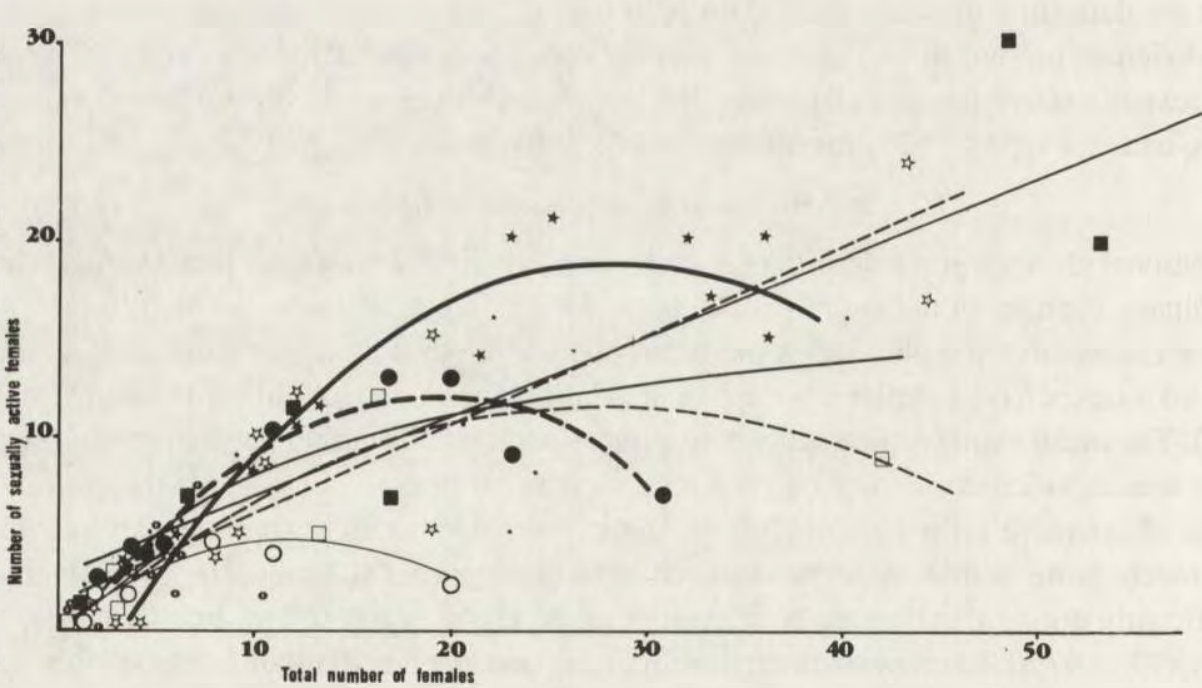

Fig. 5. The relationship between the number of sexually active females and the total number of females in specific plots.

The relation between the number of sexually active males and total number of males showed no significant differences amongst the plots. Analyzing all the data, it was found that an early increase in total number of males on different plots accompanied a proportionate increase in the number of sexually active males. A linear regression described the dependence below a maximum of 20 males on one plot. Further increases in the number of males caused a slowing in the rate of increase of the number of sexually active males. After analysis of all data from each plot, it was determined that the relation between the number of sexually active males and the total number of males is described by a logarithmic function (Fig. 6). 


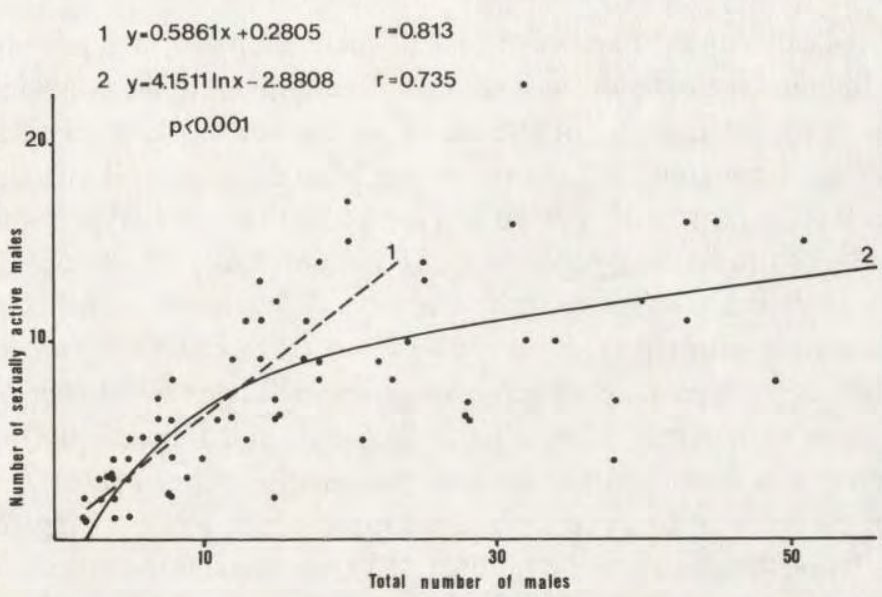

1.ig. 6. The relationship between the number of sexually active males and the total number of males. (1) For $0-20$ males toatl on a given plot, (2) Data obtained on all plots.

Table 6 . The mean number of individuals captured for the first time per sexually active female (for the entire season) on different plots.

\begin{tabular}{lcclcc}
\hline Plot & $\bar{x}$ & SD & \multicolumn{1}{c}{ Plot } & $\bar{x}$ & SD \\
\hline $\mathrm{C}_{1}$ & 7.56 & 1.31 & $\mathrm{R}_{4}$ & 3.30 & 0.35 \\
$\mathrm{C}_{2}$ & 6.48 & 0.19 & $\mathrm{R}_{5}$ & 4.79 & 1.61 \\
$\mathrm{C}_{3}$ & 5.45 & 1.85 & $\mathrm{R}_{7}$ & 4.00 & 0.95 \\
$\mathrm{C}_{6}$ & 5.88 & 0.89 & $\mathrm{R}_{8}$ & 4.71 & 0.73 \\
$\mathrm{C}_{9}$ & 4.82 & 2.02 & & & \\
All plots C & $6.02^{*}$ & 1.68 & All plots R & $4.19 *$ & 1.13 \\
\hline
\end{tabular}

$*_{t}=2.95, p<0.01$

Table 7. The mean number of individuals captured for the first time in separate trapping series per one sexually active female in the previous trapping series on type $\mathrm{R}$ and $\mathrm{C}$ plots.

\begin{tabular}{lccc}
\hline Plots & July & August & October \\
\hline C & $10.15 \pm 5.09$ & $5.06 \pm 3.87$ & $* 4.04 \pm 3.99$ \\
R & $7.71 \pm 5.58$ & $3.07 \pm 2.09$ & $* 1.75 \pm 0.62$ \\
\hline
\end{tabular}

$* t=2.12, p<0.05$ 


\section{Recruitment of individuals to the population}

The relationships between the number of sexually active females and the number of recruits to the population in both types of plots was studied. Recruitment to the population on different plots was evaluated by calculation of the mean number of newly marked individuals per sexually active female throughout the season (combining data from all years studied). In the majority of cases this value was higher on $\mathrm{C}$ type plots than on $\mathrm{R}$ type plots. The means calculated using all data for each type of plot differ significantly (Table 6). The percentage of sexually active individuals amongst those caught for the first time was higher in type $\mathrm{R}$ areas $(48 \%)$ as compared with type C plots $(39 \%)(t=3.63 ; p<0.001)$. The mean number of recruits per sexually active female during a given trapping series was lower on $\mathrm{R}$ type plots than on C type plots (calculated using all the data for each type of plot). A statistically significant difference was found only in the October trapping series (Table 7).

An analysis of recruitment to the population during subsequent trapping series was done by studying the relationship between the number of newly marked individuals during a given trapping series (July, August and October) and the number of sexually active females in the previous trapping series (in May, July and August, respectively). The data were analyzed

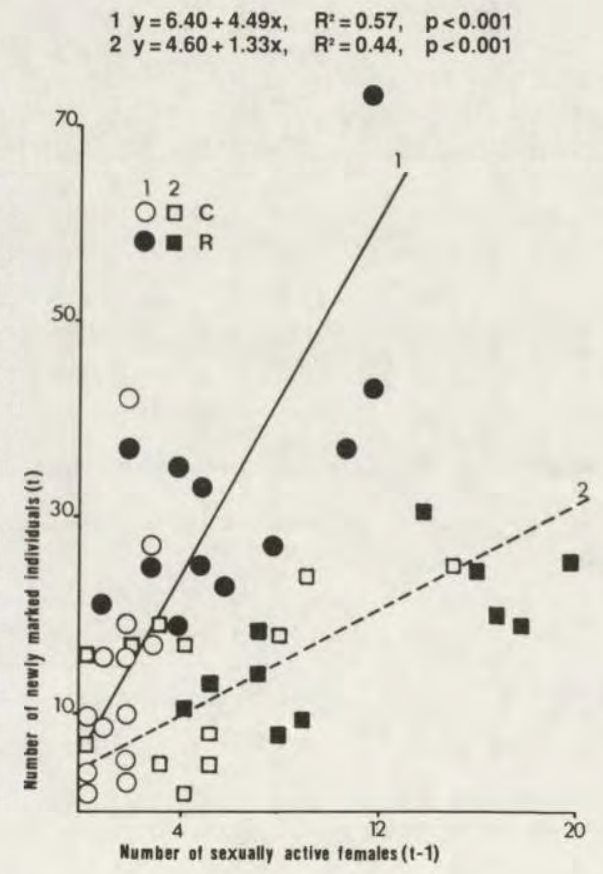

Fig. 7. The relationship between the number of recruits to the population in (1) July and (2) October and the number of sexually active females in the preceding trapping series (May and August, respectively). $\begin{array}{llr}11977 y=4.436+5.514 x-0.162 x^{2}, & R^{x}=0.795, & 0.1>p>0.05 \\ 21978 y=-115.990+122.962 \ln x-23.074(\ln x)^{2}, & R^{2}=0.979, & p<0.01\end{array}$ $\begin{array}{lll}21978 y=-115.990+122.962 \ln x-23.074(\ln x)^{2}, & R^{3}=0.979, & P<0.01 \\ 31979 y=-41.837+8.511 x-0.258 x^{2}, & R^{2}=0.717, & N S\end{array}$ $\begin{array}{lll}31979 y=-41.837+8.511 x-0.258 x^{2}, & R^{2}=0.717, & \text { NS } \\ 41980 y=-43.018+19.061 x-1.015 x^{2}, & R^{2}=0.997, & p<0.01\end{array}$

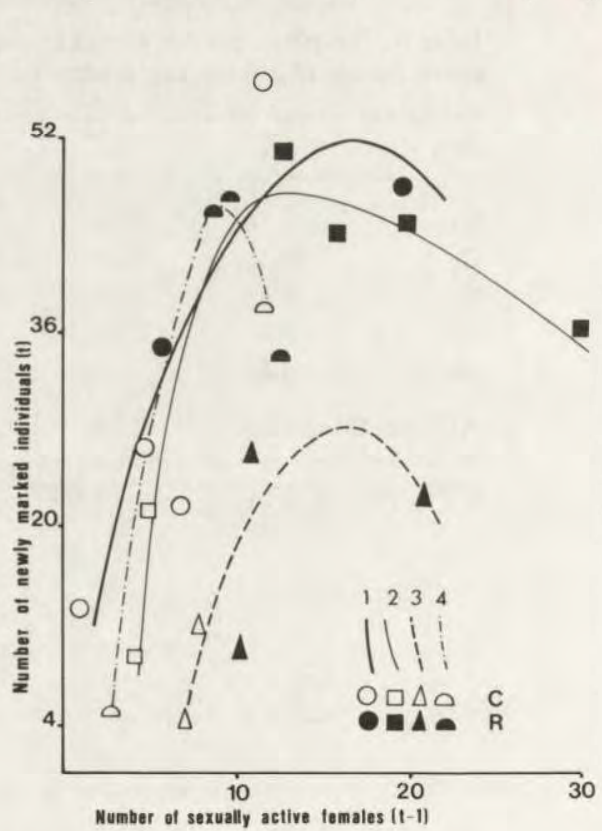

Fig. 8. The relationship between the number of recruits to the population in August and the number of sexually active females in July. 
independently for separate years of study $(1977-80)$ for the trapping series in August. Becouse I found no difference between years for the trapping series in July and October those data were analysed collectively for all years of the study. The reduced major axis method was used. It was found that the recruitment to the population in July increased proportionately to the increase in number of sexually active females present on the given plots in May (Fig. 7). For the August trapping series this relationship was curvilinear (Fig. 8). The lowest number of sexually active females in July generally caused a low number of recruits in August. The only exception was plot $\mathrm{C}_{6}$ in 1977 . The further increase in the number of sexually active females on the plots was associated with an increase in the number of recruits (per female). When the number of sexually active females surpassed a critical point, which was different for each year studied, a drop followed in the number of recruits to the population. This inhibition of recruitment between July and August existed primarily on R type plots (Fig. 8).

In October, the number of recruits to the population increased proportionately to the number of sexually active females on a given plot, but much more slowly than in previous trapping series. The ratio of recruits to sexually active females was lower on $\mathrm{R}$ type than on $\mathrm{C}$ type plots (Fig. 7) as in the August series.

\section{Disappearance of individuals from the population}

Disappearance from the population was estimated as the percentage of previous year counts which did not persist through the winter (October-May) and the percentage of current year individuals which were found to be missing in the trapping series immediately following the one in which they were marked. This was calculated separately for those captured for the first time in July and in August. Data gathered from the plots in which trappings were carried out for successive years were grouped together and analyzed. The same was done for type R and $\mathrm{C}$ plots, grouping material from all years. Comparison of missing current year individuals on type $\mathrm{R}$ and $\mathrm{C}$ plots was carried out both separately for sexually active and inactive individuals and combined. The rate of disappearance of individuals was calculated for the winter period in type R and C plots, and for individuals marked in July and August, using the equation:

$$
\mu=\frac{\ln (\mathrm{No})-\ln (\mathrm{N} t)}{\mathrm{T}}
$$

where $\mathrm{T}$ - time which has passed between the initial and subsequent estimates of the number of individuals in the analyzed group $(\mathrm{N})$.

It was found that the disappearance of individuals during the winter period was similar in both types of areas (in type C areas - 90\%; type R-86\%). Disappearance was most common between 1978 and $1979(82 \%)$, and least common between 1977 and $1978(41 \%)$. The rate of disappearance was low (type $\mathrm{C}$ plots, $\mu=0.009$; type $\mathrm{R}$ plots, $\mu=0.010$ ).

Analysis of disappearance of current year individuals from the moment of marking to the following trapping series, in the separate years, showed a similiarity (individuals marked in July, $46-50 \%$; in August, $50-63 \%$ ).

The disappearance of individuals marked in July by the August trapping series was significantly lower on type R than on type C plots. However, for those marked in August 
Table 8. The percent of individuals disappearing for those marked in July and August (sample size in parentheses). Letters mark the participating pairs which differ significantly.

\begin{tabular}{lccc}
\hline $\begin{array}{l}\text { Type } \\
\text { of plot }\end{array}$ & $\begin{array}{c}\text { Sexually } \\
\text { active }\end{array}$ & $\begin{array}{c}\text { Sexually } \\
\text { inactive }\end{array}$ & $\sum$ \\
\hline \multicolumn{4}{c}{$\begin{array}{c}\text { Marked in July } \\
\mathrm{C}\end{array}$} \\
$\mathrm{R}$ & $0.48(126)$ & $0.53(53)$ & $0.51(179)^{\mathrm{b}}$ \\
& $0.41(233)$ & $0.39(166)^{\mathrm{c}}$ & $0.39(399)^{\mathrm{a}, \mathrm{b}}$ \\
$\mathrm{C}$ & $0.48(69)$ & $0.58(198)$ & $0.55(267)$ \\
$\mathrm{R}$ & $0.41(95)$ & $0.66(313)^{\mathrm{c}}$ & $0.58(408)^{\mathrm{a}}$ \\
\hline${ }^{\mathrm{a}} t=5.58, p<0.001 ;{ }^{\mathrm{b}} t=3.01, p<0.01 ;{ }^{\mathrm{c}} t=5.82, p<0.001$.
\end{tabular}

there were similarities on both types of plots (Table 8). On type $\mathrm{C}$ plots, no differences were observed in the disappearance of individuals marked in July and August. On type R plots, the disapperance of individuals marked in August was significantly higher than the disappearance of those individuals marked in July. Sexually inactive individuals showed a greater tendency towards disappearance than sexually active individuals on both types of plots (Table 8). The disappearance rate of individuals marked in July was lower (for type C plots, $\mu=0.015$; for type $R, \mu=0.011)$ than for individuals marked in August $(\mu=0.017$ and 0.019 , respectively). The disappearance rate of those marked in July on type R plots was similar to the disappearance rate for the winter season.

In order to study whether the identified differences in the disappearance of individuals from type $\mathrm{R}$ and $\mathrm{C}$ plots influenced the age structure of the population, the percentage

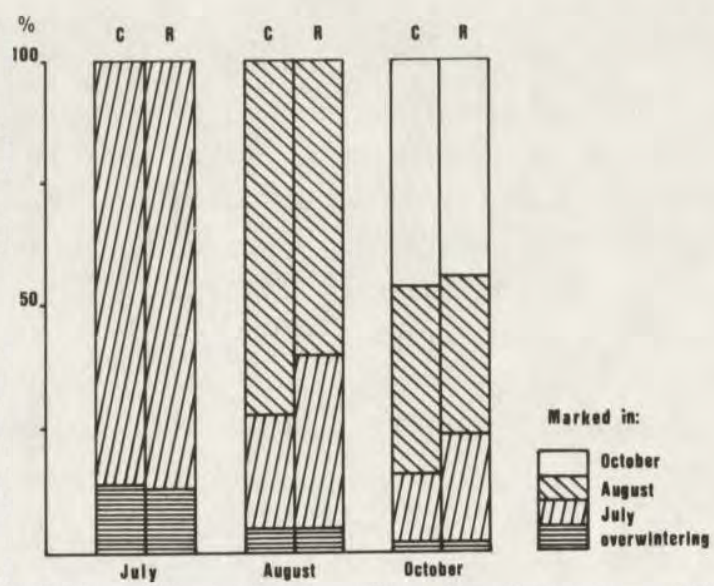

Fig. 9. The percentage distribution of individuals marked at different times in successive trapping series. 
distribution of individuals marked at different times on both types of plots for a trapping series in July, August and October was calculated.

It was found that in July the percent of individuals captured for the first time and overwinted animals were similar on both types of plots. In August, when the percent of overwinted animals was similar on both types of plots, a significantly higher percent of individuals marked in July $(t=3.35 ; p<0.001)$ was observed. A correspondingly lower percent of newly marked individuals in the same series in type $\mathrm{R}$ plots was observed when compared with type $\mathrm{C}$ plots. In October, the percent of individuals marked earlier was similar. However, the percent of individuals marked in July was significantly higher in type $\mathrm{R}$ areas than in type $\mathrm{C}$ areas $(t=2.56 ; p<0.002)$ (Fig. 9).

These results, as well the relationship between the number of recruits to the population and the number of sexually active females reported in the previous section, suggest that the current density of individuals on a given plot may influence the recruitment to the population. Thus, the relationship of the number of individuals marked earlier and the mean number of recruits per sexually active female in the previous series was studied. The data for the August and October trapping series did not differ and were therefore analyzed together for all years. For both the August and October series, it was observed that along with an increase in the number of marked individuals which persisted from the previous trapping series on given plots the number of recruits per sexually active female decreased. During the August series, the empirical values for areas $\mathrm{C}_{6}, \mathrm{C}_{9}$, and $\mathrm{R}_{7}$ in 1979 deviated greatly from the theoretical curve. The same was found for $C_{1}$ in 1976 and $C_{9}$ in 1979 for the October series. All of these cases

Fig. 10. The relationship between the number of newly individuals in (1) August and (2) October per one sexually active female in the previous trapping series (July and August, respectively) and the number of individuals which persisted from the preceding trapping series.

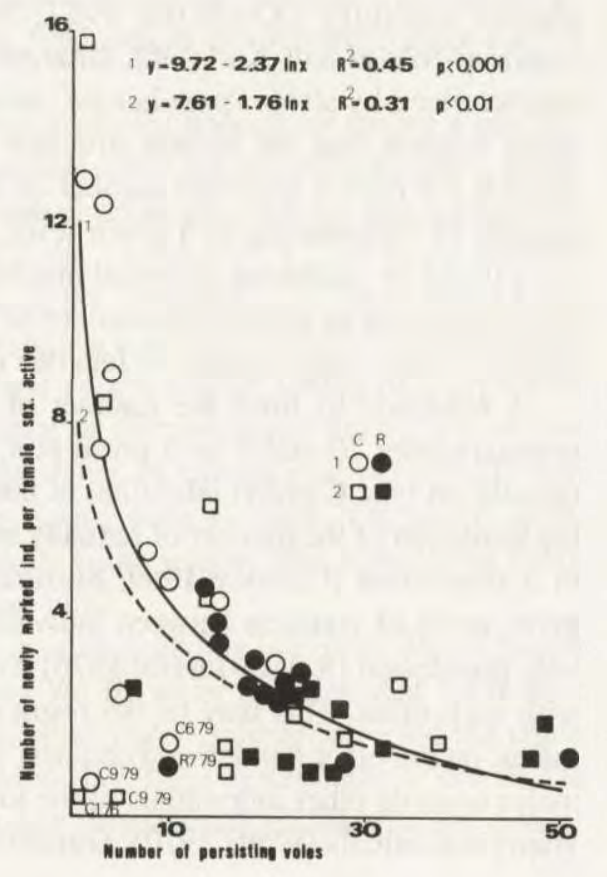


were associated with low population numbers of the bank vole on type $\mathrm{R}$ plots which were directly adjacent to type $\mathrm{C}$ plots $\left(\mathrm{C}_{6}\right.$ and $\mathrm{R}_{4} ; \mathrm{C}_{9}$ and $\left.\mathrm{R}_{7}\right)$, as well as low population numbers in 1976 and 1979. After discarding these data, the relation between the number of recruits and the number of individuals which persisted from the previous trapping series takes the form of a logarithmic function: $\mathrm{Y}=12.32-(3.17) \ln \mathrm{x}$ for the August series and $\mathrm{Y}=12.64-(3.32)$ $\ln \mathrm{x}$ for the October series. The determination coefficients increase correspondingly to $\mathrm{R}^{2}=$ 0.79 for the August series and $\mathrm{R}^{2}=0.75$ for the October series. The high survival rates of individuals, and associated with it low number of recruits per sexually active female, occured primarily on R type plots (Fig. 10).

\section{Discussion}

One of the parameters differentiating populations of voles living in habitats with different stand structure was the number of sexually active females. On plots where the undergrowth was distributed more uniformly (type R) the number of sexually active females was higher than on plots where it was more clustered (type C). Earlier studies showed that on both types of plots sexually active females had non-overlapping home ranges independent of their density Mazurkiewicz 1986). In bank vole populations, as in other species of the genus Clethrionomys, a reproduction limitation occurs (Kalela 1957, Koshkina 1965, Jewell 1966, Bujalska 1970, 1985, Koshkina and Korotkov 1975, Saitoh 1981). It is associated with the territorial tendencies of sexually mature females during the reproductive season (Naumov 1951, Tanaka 1953, Koshkina 1965, Aristova 1970, Bujalska 1973, Koshkina and Korotkov 1975, Saitoh 1985). The number of territories of females reproducing in a given habitat depends on its food and shelter capacity (Koshkina 1957, Ryszkowski 1971, Koshkina and Korotkov l.c., Bondrup-Nilson and Karlsson). Biotopes with well-developed shrub and sapling layers are characterized by stable "populations" of reproducing females (Wiger 1982). The results of this study suggest that the habitat structure of the various plots create reproductive conditions suitable for only a specified number of females. The stabilization of the number of females capable of reproducing at a given level, depending on the environmental conditions, occurs most likely by inhibition of sexual maturation. Only on plots where the stand was undergoing succession was an increase in number of sexually active females that was proportionate to the increase in the total number of females in the population observed.

A tendency to limit the number of sexually active males occurred above densities of approximately 20 males on a given plot. Thus on plots where the number of males was low (mostly on type $\mathrm{C}$ plots) inhibition of their sexual maturation was not observed. It seems that the limitation of the number of sexually active males possessing large overlapping tome ranges in a population (Crawley 1969, Mazurkiewicz 1971, Bondrup-Nielsen 1986) maintaining a given norm of contacts between individuals. Studies on the social organization of the bank vole population (Rajska-Jurgiel 1976) have indicated that sexually active males avoid contact with each other. This may be the result of previous aggressive encounters. Sexually inactive males, on the other hand, avoid contacts with sexually active ones. The aggressiveness of older males towards other individuals of the same sex can lead to inhibition of sexual maturation in young individuals (Watts 1970a, Gustaffson et al. 1983, Gustaffson 1985). The higher number 
of sexually active males on type $\mathrm{R}$ plots than on type $\mathrm{C}$ plots was probably a result of the higher population density. We cannot, however, falsify the alternative interpretation that the habitat structure on those plots allowed better chances to avoid negative contacts and therefore permitted residency of a larger number of sexually active males. Smal and Fairley (1981) found a higher density of male bank voles in habitats of dense plant cover and complex ground topography as compared with habitats with sparse plant cover and even ground.

As a result of inhibition of individual sexual maturation, winter survivors and individuals born at the beginning of the reproductive season, were responsible for most reproduction. Similar results concerning females were obtained by Bujalska et al. (1968) for island populations of the bank vole.

The different levels of seasonal changes of bank vole population density on separate plots and a higher density on type $\mathrm{R}$ plots as compared with type $\mathrm{C}$ plots, can be associated with a varying intensity of reproduction becouse of different number of sexually active females. The pattern of recruitment to the population during the season indicates, however, that after a period of quick growth, when the number of recruits to the population was proportionate to the number of overwintering females, a period of inhibition of recruitment to the population, especially on R type plots, followed. In the fall, when recruitment to the population was generally low, the recruitment to type $\mathrm{R}$ plots was still lower than to type $\mathrm{C}$ plots. These results, as well as a higher number of recruits than would be expected based on the number of sexually active females in type $\mathrm{C}$ areas, as compared to type $\mathrm{R}$ areas, suggest that the type $\mathrm{R}$ areas fill up more quickly (early summer). Individuals born in later periods emigrate to other habitats, such as type C. Earlier studies (Mazurkiewicz 1986) have shown that the rate of occupation of free space by bank voles as the population density increased was faster on type R plots than on type $C$ plots. A faster occupation of optimal, rather than sub-optimal, habitats was found also for island populations of the bank vole (Mazurkiewicz 1981, Mazurkiewicz and Rajska-Jurgiel 1975).

An inverse relationship between the number of recruits to the population during a specific trapping series and the number of individuals still present since the previous trapping series indicates that recruitment to the population was dependent on its density in a given area. The few exceptions to this rule confirm the theory that the recruitment to the population in sub-optimal biotops is dependent, to a large extent, on the immigration of individuals from optimal biotopes. The residency of individuals in their place of birth seems to be dependent on the food and shelter capacity of a given habitat and on the precise timing of recruitment to the population. This may explain difference in rates of disappearance during the season between type $\mathrm{R}$ and $\mathrm{C}$ plots. On type $\mathrm{R}$ plots, disappearance of current year individuals rose during the season and was lower than on type $\mathrm{C}$ plots during early summer. On type $\mathrm{C}$ plots, the disappearance was high and consistent throughout the entire season. The recruitment index was also high, indicating a high turnover rate on these plots.

The plots on which the studies were carried out were penetrated by buzzards (Buteo buteo) and tawny owls (Strix aluco, two pair nested on plot $\mathrm{C}_{1}$ ). It can be assumed that the habitat factor (in this case, density and spatial distribution of shrubs and saplings) affected the space usage by the bank vole on the two types of plots. More favorable environmental conditions on type R plots, associated with a less potential danger from predators, allowed for a safer 
penetration of the area by individuals and for more suitable places for living. On type $\mathrm{C}$ plots, the habitat structure force animals to emigrate or live in a smaller area. Earlier results (Mazurkiewicz 1986) indicate that, on plots with clustered undergrowth, individuals used less area and lived in a higher local density (per trapping point used) than on plots with uniform undergrowth distribution.

The results seem to agree with Anderson (1980) model of the use of various habitats by microtine species. Type R plots are survival areas, optimal in the gradient of decreasing suitability, characterized by high density, high reproduction, and high survival rate of recruits at the beginning of the season. Thus, they are responsible for most of the reproduction, and thus have high emigration and low immigration rates. Type $\mathrm{C}$ plots are habitats that are traversed or colonized. They are not densely populated, but have a highly saturated space suitable for living, a high turnover of individuals and a high recruitment rate to the population. Recruitment results mainly from immigration rather than reproduction on a given plot. The objective of the present study is to evaluate the influence of certain environmental factors on processes within the population which cause seasonal and multi-annual changes in the density of the bank vole population in various forest ecosystems. The results indicate that long term, in-depth studies of the bank vole population itself, and the environmental conditions in which the voles live, are necessary to learn about the functioning of the bank vole population in the mosaic of forest ecosystems. Quantification of the intensity and direction of dispersal of voles among habitats as well as the seasonal dynamics of occupancy of habitats with different amounts of plant cover are particularly important.

Acknowledgements: I would like to thank H. Plewka, J. Pawelski, K. Banach and A. Bartha for help in the fieldwork and preliminary preparation of the data; T. and H. Traczyk for preparing the phyto-sociological characteristics of the study plots; my colleagues from the Department of Vertebrate Ecology, especially E. Rajska-Jurgiel, for insights and comments to the first copy of the manuscript; my husband, A. Wasilewski, who devoted much time to the meritorious discussion and statistical analysis of the data; Stephen F. Lesniewski for translation of the text into English; B. Van Horne and W. Z. Lidicker Jr., for reading English version of the manuscript and making helpful comments.

\section{References}

Abramsky Z. 1981. Habitat relationships and competition in two Mediterranen Apodemus sp. Oikos 36: $219-225$.

Adler G. H. 1986. Influence of habitat structure on demography of two rodent species in eastern Massachusetts. Can. J. Zool. 65: $903-912$.

Adler G. H. and Wilson M. L. 1987. Demography of a habitat generalist the white-footed mouse in a heterogeneous environment. Ecology 68: 1785 - 1796 .

Anderson P. K. 1980. Evolutionary implications of microtine behavioral systems on the ecological stage. The Biologist 62: $70-88$.

Aristova V. A. 1970. Osobennosti ispolzovanija tieritorii krasnoj polevki w lesach jużnoj časti Kirovskoj oblasti. Fauna i Ekologija Gryzunov 9: 151 - 159.

Ashby K. R. 1967. Studies on the ecology of fields mice and voles (Apodemus sylvaticus, Clethrionomys glareolus and Microtus agrestis) in Houghall Wood, Durham. J. Zool. 152: 389-512.

Birkan M. 1968. Repartition ecologique de populations d'Apodemus sylvaticus et Clethrionomys glareolus en pinede a Ramboillet. La Terre et la Vie 22: 231 - 273.

Bondrup-Nielsen S. 1986. Demography of Clethrionomys gapperi in different habitats. Can. J. Zool. 65: $277-283$. 
Bondrup-Nielsen S. and Karlsson F. 1985. Movements and spatial patterns in population of Clethrionomys species: A review. Ann. Zool. Fennici. 22: 385 - 392.

Bower M. A. and Smith M. D. 1979. Differential habitat utilization by sexes of deer mouse, Peromyscus maniculatus. Ecology 60: $869-875$.

Brown L. E. 1956. Field experiments on the activity of the small mammals Apodemus, Clethrionomys and Microtus. Proc. Zool. Soc. London 126: 549 - 564.

Bujalska G. 1970. Reproduction stabilizing elements in an island population of Clethrionomys glareolus (Schreber, 1780). Acta theriol. 15: $381-412$.

Bujalska G. 1973. The role of spacing behaviour among females in the regulation of the reproduction in bank vole. J. Reprod. Fert., Suppl. 19: $465-474$.

Bujalska G. 1985. Fluctuation in an island bank vole population in the light of the study on its organization. Acta theriol. 30: 3 - 49 .

Bujalska G., Andrzejewski R. and Petrusewicz K. 1968. Productivity investigation of an island population of Clethrionomys glareolus (Schreber, 1780). II Natality. Acta theriol. 13: 415 - 425.

Cockburn A. 1981. Population regulation and dispersion of the smoky mouse Pseudomys fumeus. II. Spring decline, breeding success and habitat heterogeneity. Australian J. of Ecology 6: 255 - 266.

Cockburn A. and Lidicker W. Z., Jr. 1983. Microhabitat heterogeneity and population ecology of an herbivorous rodent, Microtus californicus. Oecologia 59: 167 - 177.

Crawley M. C. 1969. Movements and home-ranges of Clethrionomys glareolus $\mathrm{L}$. in north-east England. Oikos 20: $310-319$.

Crowell W. and Pimm S. L. 1976. Competition and niche shifts of mice introduced onto small islands. Oikos 27: $251-258$.

Errington P. L. 1983. Muskrat populations. Iowa State Univ. Press: $1-665$.

Evans F. C. 1942. Studies of a small mammal population in Bagley Wood, Berkshire. J. Anim. Ecol. 11: $182-197$.

Fordham R. A. 1971. Field populations of deer mice with supplemental food. Ecology 52: 138 - 146.

Goodwin J. G., Jr. and Hungerford C. R. 1979. Rodent population densities and food habits in Arizona ponderosa pine forests. Research Paper RM-214, United States Forest Service, Washington D.C., USA.

Gubar J. P. 1974. Stacji krasnoj polevki (Clethrionomys rutilus Pall.) Onežskogo poluostrova. Fauna i Ecol. Živ. Nauka, Moskva: $174-188$.

Gustafsson T. O. 1985. Sexual maturation in Clethrionomys. Ann. Zool. Fenn. 22: 303-308.

Gustafsson T. O., Anderson C. B. and Nyholm N. E. J. 1983. Comparison of sensititivity to social suppresion of sexual maturation in captive male bank voles, Clethrionomys glareolus originating from populations with different degrees of cyclicity. Oikos 41: 250-254.

Hansson L. 1971. Small rodent food, feeding and population dynamics. A comparison between granivorous and herbivorous species in Scandinavia. Oikos 22: $183-198$.

Hansson L. 1978. Small mammal abundance in relation to environmental variables in three Swedish forest phases. Stud. Forest. Snee. 147: 5-39.

Ivanter E. V. 1975. Populacjonnaja ekologija melkih mlekopitajuščih taežnogo severo-zapada SSSR. Izd. Nauka, Leningrad: $1-246$.

Jensen T. S. 1982. Habitat distribution, home range and movements of rodents in mature forest and reforestation. Acta. Zool. Fenn. 171: 305 - 307.

Jewell P. A. 1966. Breeding season and recruitments in some British mammals confined on small islands. Symp. Zool. Soc. London 15: $89-116$.

Kalela O. 1957. Regulation of reproduction rate in subarctic populations of the vole Clethrionomys rufocanus (Sund). Ann. Acad. Sci. fenn., Ser. A 4: 7-60.

Kalela O. 1962. On the fluctuations in the numbers of arctic and boreal small rodents as a problem of production biology. Ann. Acad. Sci. fenn., Ser. A, IV, 66: 1-38.

Košhkina T. V. 1957. Sravnitelnaja ekologija ryžih polevok v severnoj taige. Mat. po Gryzunam. Fauna i Ekologija Gryzunov 5:3-65. 
Košhkina T. V. 1965. Plotnost' populacii i ee značenie v regulacii čislennosti krasnoj polevki. Bjul. Mosk. Obšč. Isp. Prir. Otd. biol. 70: 5- 19.

Košhkina T. V. and Korotkov Yu. S. 1975. Regulative adaptations in populations of the red vole (Clethrionomys rutilus) under optimum conditions in its range. Fauna i Ekologija Gryzunov 12: 5 - 61. [In Russian with English summary]

Kovalevsky J. V., Karpenko E. J. and Katenina N. D. 1971. Methods for large-scale mapping of the distribution and abundance of small forest rodents. Fauna i Ekologija Gryzunov 10: 172 - 186. [In Russian with English summary]

Kovalevsky J. V. and Korenberg E. J. 1976. The determination of the norm of quantitative accuonts of forest muridae under the large-scale mapping of their distribution, (in Russia). Zool. Ž. 7: 1079 - 1085. [In Russian]

Kozakiewicz M. 1985. The role of habitat isolation in formation of structure and dynamics of bank vole population. Acta theriol. 30: $193-209$.

Lapin J. M. 1963. Biologija i parazitofauna melkih lesnyh mlekopitajuščih Latvijskoj SSR. Izd. AN LSSR, Riga: $1-135$.

Lidicker W. Z., Jr. 1975. The role of dispersal in the demography of small mammals. [In: Small mammals: their productivity and population dynamics. F. B. Golley, K. Petrusewicz and L. Ryszkowski, eds]. Cambridge University Press, Cambridge, England: 103 - 134.

Mazurkiewicz M. 1971. Shape, size and distribution of home range of Clethrionomys glareolus (Schreber, 1780). Acta. theriol. 16: $23-60$.

Mazurkiewicz M. 1981. Spatial organization of a bank vole popuation in years of small or large numbers. Acta theriol. 26: $31-45$.

Mazurkiewicz M. 1984. Population density of small rodents as affected by chosen elements of tree stand structure. Bull. Acad. Pol. Sci. Cl II 32: 209 - 217.

Mazurkiewicz M. 1986. The influence of undergrowth distribution on utilization of space by bank vole populations. Acta theriol. 31: $55-69$.

Mazurkiewicz M. and Rajska-Jurgiel E. 1975. Dispersion of bank voles from their place of birth. Acta theriol. 20: $71-81$

Mazurkiewicz M. and Rajska-Jurgiel E. 1978. Size and structure of rodent community of various forest stand types. Bull. Acad. Pol. Sci. Cl II 10: 669 - 677.

M'Closkey R. T. 1975. Habitat succession and rodent distribution. J. Mammal. 56: 950 - 955.

M'Closkey R. T. 1981. Microhabitat use in coexisting desert rodents - the role of population density. Oecologia (Berl) 50:310-315.

Miller D. H. and Getz L. L. 1972. Factors influencing the local distribution of the red backed vole Clethrionomys gapperi in New England. Univ. Connecticut. Occas. Papers, Biol. Sci. Ser. 2: 115 - 138.

Miller D. H. and Getz L. L. 1973. Factors influencing the local distribution of the red backed vole Clethrionomys gapperi in New England. II. Vegetation cover, soil moisture and debris cover. Univ. Connecticut Occas. Papers, Biol. Sci. Ser. 2: 159 - 180.

Miller D. H. and Getz L. L. 1977. Factors influencing local distribution and species diversity of forest small mammals in New Zeland. Can. J. Zool. 55: $806-814$.

Morisita M. 1959. Measuring of the disperssion of individuals and analysis of the distributional patterns. Mem. Fac. sci. Kyushu Univ., E. Biol. 2: 4.

Naumov N. B. 1951. Novyj metod izučenija ekologii melkih lesnyh gryzunov. Fauna i Ekologija Gryzunov 4: $3-21$.

Newson R. 1963. Differences in numbers, reproduction and survival between two neighbouring populations of bank voles (Clethrionomys glareolus). Ecology 44: 110 - 120 .

Ostfeld R. S. and Klosterman L. L. 1986. Demographic substructure in a California vole population inhabiting a patchy environment. J. Mammal. 67: 693 - 704 .

Ostfeld R. S., Lidicker W. Z., Jr. and Heske E. G. 1985. The relationship between habitat heterogeneity, space use, and demography in a population of California voles. Oikos 45: $433-442$. 
Petrov O. V. 1965. Značenie lesnyh očagov v žizni myševidnyh gryzunov lesostepnyh dubrav, Vest. Leningr. Univ. Biol. 9: $26-32$.

Petrusewicz L. 1966. Dynamics, organization and ecological structure of population. Ecol. Pol. A 14: $413-436$.

Pitelka F. A. 1957. Some aspects of population structure in the short-term cycle of brown lemming in northern Alaska. Cold Spring Marbor Symp. guant. Biol. 22: 237 - 251.

Popov V. A. 1966. Mlekopitajuščije Volžsko-Kamskogo Kraja. Izd. AN SSSR, Kazanskij Filial, Kazan: $1-467$.

Rajska-Jurgiel E. 1976. Interactions between individuals of a population of the bank vole Clethrionomys glareolus (Schreber, 1780). Ecol. Pol. A 24: 3-35.

Ryszkowski R. 1971. Reproduction of bank voles and survival of juvenilles in different pine forest ecosystems. Ann. Zool. fenn. 8: 85 - 91 .

Saitoh T. 1981. Control of female maturation in high density populations in the red backed Clethrionomys rufocanus bedfordiae. J. Anim. Ecol. 50: 79 - 87 .

Smal C. M. and Fairley J. S. 1981. The dynamics and regulation of small rodent population in the woodland ecosystems of Killarney, Ireland. J. Zool. Lond. 196: 1-30.

Spencer S. R. and Cameron G. N. 1983. Behavioral dominance and its relationship to habitat patch utilization by the hispid cotton rat (Sigmodont hispidus). Behav. Ecol. Sociobiol. 13: 27-36.

Taitt M. J. and Krebs C. J. 1981. The effect of extra food on small rodent populations - II. Voles (Microtus townsendii). J. Anim. Ecol. 50: 125 - 137.

Tanaka R. 1953. Home range and territories in the Clethrionomys population on a peat-bog grassland in Hokkaido. Bull. Kochi. Wom. Coll. 2: 10 - 20.

Thomson D. Q. 1955. The role of food and cover in population fluctuations of the brown lemming at Pt. Barrow, Alaska. Trans. 20th N. Am. Wildl Conf: $166-176$.

Van Horne B. 1981. Demography of Peromyscus maniculatus populations in several stages of coastal coniferous forest in southeast Alaska. Can. J. Zool. 59: 1045 - 1961.

Van Horne B. 1982a. Demography of the longtail vole Microtus longicaudus in several stage of coastal coniferous forest in southeast Alaska. Can. J. Zool. 60: 1690 - 1709.

Van Horne B. 1982b. Niches of adult and juvenils deer mice (Peromyscus maniculatus) in seral stages of coniferous forest. Ecology 63: $992-1003$.

Van Horne B. 1983. Density as a misleading indicator of habitat quality. J. Wild. Manage. 47: $893-901$.

Viitala J. 1977. Social organization in cyclic subarctic population of the voles Clethrionomys rufocanus (Sund) and Microtus agrestis (L.). Ann. Zool. Fenn. 14: 53 - 93.

Watts C. H. S. 1970a. A field experiment on intraspecific interaction in the red-backed vole Clethrionomys gapperi. J. Mammal. 51: 331 - 347 .

Wiger R. 1982. Roles of self regulatory mechanisms in cyclic populations of Clethrionomys with special reference to $C$. glareolus, a hypothesis. Oikos 38: 60-71.

Received 25 February 1989, revised 25 August 1991, accepted 3 September 1991. 